\title{
PENGARUH PUPUK GREEN TONIK DAN PUPUK NPK MUTIARA TERHADAP PERTUMBUHANDAN HASIL TANAMAN JAGUNG MANIS (Zea mays saccharata Sturt.) VARIETAS BONANZA
}

\author{
Simon Savang Huvat ${ }^{1}$ \\ ${ }^{1}$ Agroteknologi, Fakultas Pertanian, Universitas 17 Agustus 1945 Samarinda, Indonesia. \\ E-Mail: simon92@gmail.com
}

\begin{abstract}
ABSTRAK
Pengaruh Pupuk Green Tonik dan Pupuk NPK Mutiara Terhadap Pertumbuhan dan Hasil Tanaman Jagung Manis (Zea mays saccharata L.) Varietas Bonanza. Tujuan penelitian untuk mengetahui pengaruh Green Tonik dan pupuk NPK Mutiara serta interaksinya, serta untuk mengetahui konsentrasi pupuk Green Tonik dosis dan pupuk NPK Mutiara yang tepat untuk pertumbuhan dan hasil tanaman jagung manis yang terbaik.

Penelitian menggunakan percobaan faktorial 3 x 4 dalam Rancangan Acak Kelompok (RAK) dengan 3 (tiga) kelompok. Faktor I adalah Jenis Konsentrasi Pupuk Green Tonik (G), terdiri atas 3 taraf, yaitu : tanpa pupuk Green Tonik $\left(\mathrm{g}_{0}\right)$, konsentrasi pupuk Green Tonik $2 \mathrm{ml} / \mathrm{l}$. air $\left(\mathrm{g}_{1}\right)$, dan konsentrasi pupuk Green Tonik 4 $\mathrm{ml} / \mathrm{l}$.air $\left(\mathrm{g}_{3}\right)$. Faktor II adalah Dosis Pupuk NPK Mutiara (M), terdiri atas 4 taraf, yaitu : tanpa pupuk NPK Mutiara atau kontrol $\left(\mathrm{m}_{0}\right)$, dosis pupuk NPK Mutiara $100 \mathrm{~kg} / \mathrm{ha}$ setara $48 \mathrm{~g} /$ petak $\left(\mathrm{m}_{1}\right)$, dosis pupuk NPK Mutiara $200 \mathrm{~kg} / \mathrm{ha}$ setara $96 \mathrm{~g} /$ petak $\left(\mathrm{d}_{3}\right)$, dan dosis pupuk $300 \mathrm{~kg} / \mathrm{ha}$ setara $144 \mathrm{~g} /$ petak $\left(\mathrm{m}_{3}\right)$

Perlakuan pupuk Green Tonik tidak berpengaruh nyata terhadap parameter umur keluar bunga jantan, umur keluar bunga betina, umur panen, panjang tongkol dan diameter tongkol. Berpengaruh sangat nyata terhadap tinggi tanaman umur 4 minggu dan umur 6 minggu setelah tanam serta produksi tongkol. Produksi tongkol tertinggi terdapat pada perlakuan $\mathrm{g}_{2}$ (konsentrasi pupuk Green Tonik $4 \mathrm{ml} / \mathrm{l} . \mathrm{air}$ ), yaitu 16,60 ton/ha, sedangkan produksi tongkol terendah terdapat pada perlakuan $\mathrm{g}_{0}$ (tanpa pupuk Green Tonik atau kontrol), yaitu 16,14 ton/ha.

Perlakuan pupuk NPK Mutiara berpengaruh nyata terhadap parameter panjang tongkol. Produksi tongkol tertinggi terdapat pada perlakuan $\mathrm{m}_{3}$ (dosis pupuk NPK Mutiara $300 \mathrm{~kg} / \mathrm{ha}$ ), yaitu 17,23 ton/ha.
\end{abstract}

Kata kunci : Jagung manis, Pertumbuhan, Pupuk green tonik, Pupuk NPK Mutiara.

\begin{abstract}
Effect of Green Tonic Fertilizer and NPK Mutiara Fertilizer on the Growth and Production of Sweet Corn (Zea mays saccharata L.) Bonanza Variety. The purpose of this research is to study the influence of Green Tonic and NPK Mutiara fertilizer and its interaction, and to find the proper concentration of Green Tonik fertilizer and dosage of NPK Mutiara fertilizer for the best growth and produciton of sweet corn.

The research used $3 \times 4$ factorial experiment in Randomized Block Design (RAK) with 3 (three) replications. Factor I was the concentration of Green Tonic Fertilizer $(G)$, consisting of 3 levels, namely: no Green Tonic fertilizer application or control $\left(g_{0}\right), 2 \mathrm{ml} /$.water $\left(g_{l}\right)$, and $4 \mathrm{ml} /$ water $\left(g_{3}\right)$. Factor II was Dosage of NPK Mutiara Fertilizer (M), consist of 4 level, that was: no NPK Mutiara application or control $\left(\mathrm{m}_{0}\right), 100 \mathrm{~kg} / \mathrm{ha}$ equal to $48 \mathrm{~g} / \mathrm{plot}\left(\mathrm{m}_{1}\right), 200 \mathrm{Kg} / \mathrm{ha}$ equal to $96 \mathrm{~g} / \mathrm{plot}\left(d_{3}\right)$, and $300 \mathrm{~kg} / \mathrm{ha}$ equial to $144 \mathrm{~g} / \mathrm{plot}\left(\mathrm{m}_{3}\right)$.

The results showed thattreatment of Green Tonic fertilizer do not affect significantly on the age of male flowers emerged, age of female flower emerged, age of crop harvested, length of cob and diameter of cob. But it affected very significantly on the plant height at ages 4 weeks and 6 weeks after planting and cob production. The highest production was attained at the treatment of $g_{2}$ (concentration of Green Tonik fertilizer $4 \mathrm{ml} / \mathrm{l}$.water), ie 16.60 tons/ha, while the lowest one was at the $g_{0}$ treatment (no Green Tonic application or control), 16.14 tons/Ha.

NPK Mutiara fertilizer treatment significantly affected the parameters of cob length. The highest production of Tuna was found in the 33 treatment (NPK fertilizer dosage $300 \mathrm{~kg} / \mathrm{ha}$ ), which was 17.23 tons / ha.
\end{abstract}

Key words : Green tonic fertilizer, Growt, NPK Mutiara fertilizer, Sweet corn. 


\section{PENDAHULUAN}

Jagung manis (Zea mays saccharata Sturt) atau sweet corn, merupakan salah satu jenis tanaman jagung yang banyak disukai masyarakat, hal ini disebabkan mempunyai rasa yang lebih manis dari pada jagung biasa. Tanaman ini mempunyai prospek yang cukup cerah untuk dikembangkan, karena dapat diusahakan sepanjang tahun, umurnya lebih pendek (genjah) dan harganya cukup tinggi. Tanaman jagung manis juga bisa dimanfaatkan untuk dipanen masih muda sebagai bahan sayuran yang mempunyai nilai gizi yang tinggi dan harga yang mampu bersaing dengan tanaman sayur-sayuran lainnya (Suprapto, 2004).

Konsumsi jagung manis terus mengalami peningkatan seiring dengan pertambahan jumlah penduduk dan pola konsumsi. Jagung manis dikonsumsi segar dalam bentuk jagung rebus maupun jagung bakar dengan atau tanpa diberi bahan lain (berbagai rasa dan aroma). Sering juga menjadi bahan baku makanan dan produk olahan, misalnya kue, roti, sayur sop, sayur asam, perkedel, cream, susu, sirup, bahan baku pembuat permen dan topping pizza (Syukur dan Rifianto, 2013).

Seiring dengan kebutuhan yang semakin meningkat, maka perlu teknik pengetahuan budidaya tanaman jagung manis yang lebuh baik, agar produksi jagung manis yang dihasilkan lebih tinggi. Salah satunya adalah melalui pemupukan.

Secara umum lahan pertanian di Kalimantan Timur di dominasi jenis tanah ultisol dengan sifat kesuburan kimia tanah relatif rendah, lahan yang demikian merupakan kendala utama untuk mengoptimalkan hasil dan produktivitas lahan usaha tani dewasa ini. Oleh karena itu tanah yang kurang subur di perlukan upaya untuk meningkatkan kondisi hara tanah agar menjadi lebih baik lagi bagi pertumbuhan tanaman.

Kondisi lahan pertanian yang kesuburannya relatif rendah, maka untuk meningkatkan produktivitas tanaman jagung dapat dilakukan dengan usaha penerapan teknologi bercocok tanam yang baik, diantaranya dengan melakukan pemupukan yang berimbang yang memenuhi unsur hara yang diperlukan tanaman, hal ini dilakukan mengingat tanaman jagung manis tidak akan memberikan hasil yang maksimal apabila unsur hara yang dibutuhkan untuk pertumbuhannya tidak cukup tersedia, terutama unsur nitrogen $(\mathrm{N})$, fospor $(\mathrm{P})$, dan kalium (K), pemberian pupuk nitrogen, fospor dan kalium merupakan kunci utama dalam usaha budidaya tanaman jagung manis (Suprapto, 2004).

Pemupukan merupakan salah satu kegiatan yang erat kaitannya dengan pertumbuhan dan produksi tanaman. Ketersediaan sumber hara N, P, dan K yang cepat direspons oleh tanaman saat ini semakin sulit diperoleh oleh petani, sehingga diperlukan informasi tentang ketersediaan hara di dalam tanah agar diketahui unsur hara yang kahat di tanah tersebut. Kegiatan ini memberikan hasil yang optimal tergantung pada beberapa faktor, di antaranya takaran dan jenis pupuk yang digunakan. Jenis dan takaran pupuk ini banyak digunakan untuk mengkaji tanggap (respons) tanaman terhadap tindakan pemupukan. Salah satu tanaman yang respons terhadap pemupukan adalah jagung.

Kebutuhan unsur hara tanaman
jagung dapat terpenuhi dengan menggunakan pupuk majenuk yang mengandung sekaligus unsur hara $\mathrm{N}, \mathrm{P}$ dan K, yaitu pupuk majemuk NPK Mutiara yang mengandung unsur N, P dan K. Pupuk NPK Mutiara banyak tersedia ditempat penelitian, yaitu tepatnya di Long Apari, Kabupaten Mahakam Hulu, yang merupakan pupuk 
bersubsidi dari pemerintah, yang memang diberikan kepada para petani, melalaui penyuluh lapangan (PPL). Disamping itu juga perlu ditambahkan pemakaian pupuk pelengkap cair (PPC), yaitu Green Tonik, yang kegunaannya untuk mempercepat pertumbuahan tanaman, mempercepat pembungaan dan meningkatkan hasil tanaman.

Berdasarkan uraian tersebut diatas, maka dilakukan penelitian dengan judul : " Pengaruh Pupuk Green Tonik dan Pupuk NPK Mutiara Terhadap Pertumbuhan dan Hasil Tanaman Jagung Manis (Zea mays saccharata Sturt) Varietas Bonanza ". Tujuan Penelitian adalah untuk mengetahui pengaruh pupuk NPK Mutiara dan pupuk Green Tonik serta interaksinya terhadap pertumbuhan dan hasil tanaman jagung manis. Untuk mengetahui dosis pupuk NPK Mutiara dan konsentrasi pupuk Green Tonik yang tepat untuk pertumbuhan dan hasil tanaman jagung manis yang terbaik.

\section{METODA PENELITIAN}

\subsection{Tempat dan Waktu}

Penelitian dilaksanakan di Lahan Balai Penyuluh Pertanian (BPP) Long Apari, Kecamatan Long Apari, Kabupaten Mahakam Hulu. Pada bulan Februari-Mei 2016.

\subsection{Bahan dan Alat}

Bahan yang digunakan dalam penelitian ini adalah : benih jagung manis varietas Bonanza, pupuk NPK Mutiara, pupuk Green Tonik, Furadan 3 G, Dithane M-45. Alat yang digunakan dalam penelitian ini, yakni : cangkul, parang, gembor, meteran, timbangan analitik, mikrokalifer, alat tulis-menulis, komputer dan kamera untuk dokumentasi.

\subsection{Rancangan Penelitian}

Penelitian ini menggunakan percobaan faktorial 3 x 4 dalam Rancangan Acak Kelompok (RAK) dengan 3 (tiga) ulangan atau blok. Faktor penelitiannya adalah sebagai berikut :

Konsentrasi Pupuk Green Tonik (G), terdiri atas 3 taraf, yaitu :

$\mathrm{g}_{0}=$ tanpa pupuk Green Tonik

$\mathrm{g}_{1}=$ konsentrasi pupuk Green Tonik

$2 \mathrm{ml} / \mathrm{l}$.air

$\mathrm{g}_{2}=$ konsentrasi pupuk Green Tonik $4 \mathrm{ml} / \mathrm{l}$.air

Dosis NPK Mutiara (M), terdiri atas 4 taraf, yaitu :

$\mathrm{m}_{0}=$ tanpa pupuk NPK Mutiara

(kontrol)

$\mathrm{m}_{1}=$ dosis pupuk NPK Mutiara 100

$\mathrm{kg} / \mathrm{ha}$ setara $48 \mathrm{~g} /$ petak

$\mathrm{m}_{2}=$ dosis pupuk NPK Mutiara 200

$\mathrm{kg} / \mathrm{ha}$ setara $96 \mathrm{~g} /$ petak

$\mathrm{m}_{3}=$ dosis pupuk NPK Mutiara 300

$\mathrm{kg} / \mathrm{ha}$ setara $144 \mathrm{~g} /$ petak

Terdapat kombinasi perlakuan $3 \times 4$ $=12$ perlakuan, dengan kelompok atau ulangan sebanyak 3 kali, maka terdapat 3 x 4 × $3=36$ unit perlakuan. Adapun kombinasi perlakuannya sebagai berikut :

$\begin{array}{ccc} & \mathrm{g}_{0} \mathrm{~m}_{0} & \mathrm{~g}_{1} \mathrm{~m}_{0} \\ & & \\ & \mathrm{~g}_{0} \mathrm{~m}_{1} & \mathrm{~g}_{1} \mathrm{~m}_{1} \\ \mathrm{~g}_{2} \mathrm{~m}_{1} & \\ \mathrm{~g}_{0} \mathrm{~m}_{2} & \mathrm{~g}_{1} \mathrm{~m}_{2} \\ \mathrm{~g}_{2} \mathrm{~m}_{2} & \\ \mathrm{~g}_{0} \mathrm{~m}_{3} & \mathrm{~g}_{0} \mathrm{~m}_{3} \\ \mathrm{~g}_{0} \mathrm{~m}_{3} & \end{array}$

\subsection{Pelaksanaan Penelitian}

Pengolahan lahan

Lahan yang ditetapkan sebagai tempat penelitian dibersihakan dari semak, gulma, sisa akar dan lainnya, kemudian tanah diolah dan digemburkan dengan menggunakan traktor tangan 
(hand traktor). Kemudian dibagi kedalam tiga (3) kelompok atau ulangan, dan tiaptiap kelompok dibuat 12 petak penelitian dengan ukuran $3 \mathrm{~m} \times 1,6 \mathrm{~m}$, sehingga terdapat 36 petak penelitian atau unit perlakuan Pengaturan tata-letak petak penelitian menggunakan acak sederhana dengan cara undian.

Pemberian pupuk dasar

Satu minggu setelah petak penelitian dibuat, lalu diberi pupuk dasar menggunakan pupuk kandang sapi dengan dosis 10 ton/ha atau tiap-tiap petak sebanyak $4,8 \mathrm{~kg} /$ petak dengan cara disebar secara merata pada setiap petak penelitian, kemudian digaru dan dicampur supaya merata.

\section{Penanaman}

Sebelum ditanam, terlebih dahulu dilakukan sortasi benih (memilih benih yang tidak cacat dengan berukuran seragam). Penanaman benih dilakukan dengan membenamkan benih pada lubang tanam yang dibuat dengan tugal sedalam $3 \mathrm{~cm}$. pada masing-masing lubang ditanami 2 benih jagung manis, kemudian ditutup kembali dengan tanah. Jarak tanam jagung $40 \mathrm{~cm}$ x $70 \mathrm{~cm}$. Pada setiap petak penelitian terdapat 16 tanaman, dalam 16 tanaman tersebut terdapat 4 tanaman sampel dan 12 tanaman pinggir atau border.

\section{Pemberian Pupuk NPK Mutiara}

Sehari setelah tanam, diberikan pupuk NPK Mutiara sesuai dengan dosis perlakuan, yaitu : tanpa pupuk NPK Mutiara atau kontrol $\left(\mathrm{m}_{0}\right)$, dosis pupuk $100 \mathrm{~kg} / \mathrm{ha}$ atau $48 \mathrm{~g} /$ petak $\left(\mathrm{m}_{1}\right)$, dan dosis pupuk $200 \mathrm{~kg} / \mathrm{ha}$ atau $96 \mathrm{~g} /$ petak, dan dosis pupuk $300 \mathrm{~kg} / \mathrm{ha}$ atau $144 \mathrm{~g} /$ petak. Pemberiannya dilakukan dengan cara disebar di permukaan tanah secara merata.

\section{Pemberian pupuk Green Tonik}

Pupuk Green Tonik diberikan sesuai dengan konsentrasi perlakuan, yaitu : tanpa pupuk Green Tonik $\left(\mathrm{g}_{0}\right)$, konsentrasi pupuk Green Tonik 2 ml/l.air $\left(\mathrm{n}_{1}\right)$, konsentrasi pupuk Green Tonik 4 ml/l.air $\left(\mathrm{m}_{2}\right)$. Interval pemberian dilakukan 7 hari sekali dan dihentikan 1 minggu menjelang panen, dengan cara disemprotkan keseluruh bagian tanaman, terutama pada bagian daun bagian bawah dan atas. Dilakukan pada pagi hari sekitar jam 09.00-10.00 wita

Pemeliharaan Tanaman di Lapangan Pemeliharaan tanaman di lapangan meliputi:

a. Penyiraman

Penyiraman tanaman dilakukan setiap hari, yaitu pada pagi hari atau sore hari, dan disesuaikan dengan kelembaban tanahnya.

b. Penjarangan

Setelah tanaman berumur 1 minggu, penjarangan dilakukan dengan menyisakan 1 tanaman yang sehat pada setiap lubang tanam.

c. Penyulaman

Penyulaman dilakukan untuk menggantikan tanaman yang mati, dan ini dilakukan sampai umur tanaman 2 minggu setelah tanam.

d. Penyiangan,

Penyiangan dilakukan untuk mengendalikan gulma yang tumbuh di sekitar tanaman dan dilakukan tiap dua minggu sekali, disesuaikan dengan keadaan gulmanya..

e. Pengendalian hama dan penyakit Pengendalian terhadap gejala serangan hama ataupun penyakit berdasarkan pada penyebab organisme pengganggu tanaman. Pengendalian menggunakan 
Furadan $3 \mathrm{G}$ untuk pengendalian nematoda dan cacing, untuk penyakit yang disebabkan oleh jamur menggunakan Dithane M45.

Panen

Pemanenan tanaman jagung manis dilakukan pada saat tanaman telah siap panen konsumsi dengan ciri-ciri keadaan tongkol masih muda dan segar, bila ditekan terasa lembut pada barisan biji jagung tersebut.

\subsection{Pengambilan dan Pengumpulan Data}

Data yang diukur dalam penelitian ini adalah sebagai berikut :

\section{Tinggi Tanaman (cm)}

Tinggi tanaman diukur pada umur 4 dan 6 minggu setelah tanam, dengan cara mengukur dari pangkal batang yang telah diberi tanda sampai ke ujung daun yang tertinggi dengan menggunakan meteran.

\section{Umur Keluar Bunga Jantan (hari)}

Umur keluar bunga jantan dihitung dengan cara melihat munculnya bunga jantan pada tanaman sampel.

\section{Umur Keluar Bunga Betina (hari)}

Umur keluar bunga betina dihitung dengan cara melihat munculnya bunga betina pertama kali pada tanaman sampel.

\section{Umur Panen (hari)}

Umur panen dihitung dengan cara melihat ciri-ciri panen buah konsumsi, mulai dari awal tanam sampai tanaman siap dipanen pada tiap tanaman sampel.

\section{Panjang Tongkol (cm)}

Panjang tongkol diukur dengan cara meletakkan meteran mulai dari pangkal tongkol jagung tanpa kelobot sampai ujung tongkol pada tiap tanaman sampel.

\section{Diameter Tongkol (cm)}

Diameter tongkol diukur dengan cara melingkarkan mikro kalifer pada bagian tengah tongkol jagung tanpa kelobot pada setiap tanaman sampel.

\section{Produksi Tongkol (ton/ha)}

Produksi tongkol per hektar dilakukan dengan cara menimbang berat buah jagung tanpa kelobot yang ada dalam petak sampel sebanyak empat (4) tanaman sampel, kemudian dikonversi ke dalam satuan hektar. Adapun rumus konversinya sebagai berikut :

$$
\text { Produksi Tongkol }=\frac{\text { luas lahan } 1 \text { ha }}{\text { luas petak produksi }} \times \frac{\text { berat buah } / \text { petak produksi }}{1000}
$$

\subsection{Analisis Data}

Untuk melihat pengaruh perlakuan pupuk Green Tonik dan pupuk NPK Mutiara serta interaksinya, maka dilakukan analisis menggunakan sidik ragam. Adapun model sidik ragam Rancangan Acak Kelompok (RAK) faktorial menurut Yitnosumarto (1993),
Bila hasil sidik ragam terhadap perlakuan tidak berpengaruh nyata (non signifikan) yang menunjukan $\mathrm{F}$. Hitung $\leq \mathrm{F}$. Tabel 5\%, maka tidak dilakukan uji lanjutan, tetapi bila hasil sidik ragam terhadap perlakuan berpengaruh nyata (signifikan) yang menunjukan F .Hitung $\geq \mathrm{F}$ Tabel 5\%, atau berpengaruh sangat nyata yang 
menunjukkan F.Hitung $\geq$ F.Tabel 1\%, maka untuk membandingkan dua rata-rata perlakuan dilakukan dengan uji Beda Nyata Terkecil (BNT) pada taraf $5 \%$.

Rumus Umum Uji BNT disajikan sebagai berikut :

$$
\text { BNT 5\% }=\text { t-Tabel }(\alpha, \mathrm{db}) \times \sqrt{\frac{2 \text { KT Galat }}{\text { r.t }}}
$$

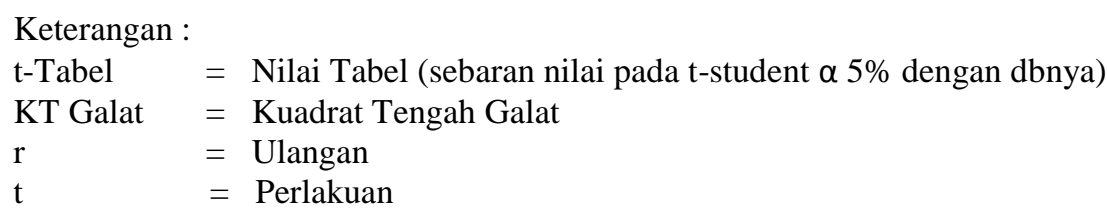

\section{HASIL PENELITIAN DAN PEMBAHASAN}

\subsection{Tinggi Tanaman Umur 4 Minggu Setelah Tanam (cm)}

Hasil sidik ragam menunjukkan bahwa perlakuan pupuk Green Tonik (G) dan perlakuan pupuk NPK Mutiara (M) berpengaruh sangat nyata, sedangkan interaksi perlakuan $(\mathrm{GxM})$ berpengaruh nyata terhadap tinggi tanaman umur 4 minggu setelah tanam (Tabel 1).

Hasil uji BNT taraf 5\% terhadap tinggi tanaman umur 4 minggu setelah tanam pada perlakuan pupuk Green Tonik (G) menunjukkan bahwa perlakuan $\mathrm{g}_{2}, \mathrm{~g}_{1}$ dan $\mathrm{g}_{0}$ satu sama lainnya saling berbeda nyata.

Hasil uji BNT taraf 5\% terhadap tinggi tanaman umur 4 minggu setelah tanam pada perlakuan pupuk NPK Mutiara (M) menunjukkan bahwa perlakuan $\mathrm{m}_{3}, \mathrm{~m}_{2}, \mathrm{~m}_{1}$ dan $\mathrm{m}_{0}$ satu sama lainnya saling berbeda nyata.

Hasil uji BNT taraf 5\% terhadap tinggi tanaman umur 4 minggu setelah tanam pada interaksi perlakuan pupuk Green Tonik dan pupuk NPK Mutiara (GxM) menunjukkan bahwa perlakuan $\mathrm{g}_{2} \mathrm{~m}_{3}$ berbeda nyata dengan perlakuan $\mathrm{g}_{1} \mathrm{~m}_{3}, \quad \mathrm{~g}_{2} \mathrm{~m}_{2}, \quad \mathrm{~g}_{0} \mathrm{~m}_{3}, \quad \mathrm{~g}_{1} \mathrm{~m}_{2}, \quad \mathrm{~g}_{0} \mathrm{~m}_{2}, \quad \mathrm{~g}_{2} \mathrm{~m}_{1}$, $\mathrm{g}_{1} \mathrm{~m}_{1}, \quad \mathrm{~g}_{0} \mathrm{~m}_{1}, \quad \mathrm{~g}_{1} \mathrm{~m}_{0}, \quad \mathrm{~g}_{0} \mathrm{~m}_{0} \quad$ dan $\quad \mathrm{g}_{2} \mathrm{~m}_{0}$.
Perlakuan $\mathrm{g}_{1} \mathrm{~m}_{3}$ tidak berbeda nyata dengan perlakuan $\mathrm{g}_{2} \mathrm{~m}_{2}$ dan $\mathrm{g}_{0} \mathrm{~m}_{3}$, tetapi berbeda nyata dengan perlakuan $\mathrm{g}_{1} \mathrm{~m}_{2}$, $\mathrm{g}_{0} \mathrm{~m}_{2}, \mathrm{~g}_{2} \mathrm{~m}_{1}, \mathrm{~g}_{1} \mathrm{~m}_{1}, \mathrm{~g}_{0} \mathrm{~m}_{1}, \mathrm{~g}_{1} \mathrm{~m}_{0}, \mathrm{~g}_{0} \mathrm{~m}_{0}$ dan $\mathrm{g}_{2} \mathrm{~m}_{0}$. Perlakuan $\mathrm{g}_{2} \mathrm{~m}_{2}$ tidak berbeda nyata dengan perlakuan $\mathrm{g}_{0} \mathrm{~m}_{3}$ dan $\mathrm{g}_{1} \mathrm{~m}_{2}$, tetapi berbeda nyata dengan perlakuan $\mathrm{g}_{0} \mathrm{~m}_{2}, \mathrm{~g}_{2} \mathrm{~m}_{1}, \mathrm{~g}_{1} \mathrm{~m}_{1}, \mathrm{~g}_{0} \mathrm{~m}_{1}, \mathrm{~g}_{1} \mathrm{~m}_{0}, \mathrm{~g}_{0} \mathrm{~m}_{0}$ dan $\mathrm{g}_{2} \mathrm{~m}_{0}$. Perlakuan $\mathrm{g}_{0} \mathrm{~m}_{3}$ tidak berbeda nyata dengan perlakuan $\mathrm{g}_{1} \mathrm{~m}_{2}$ dan $\mathrm{g}_{0} \mathrm{~m}_{2}$, tetapi berbeda nyata dengan perlakuan $\mathrm{g}_{2} \mathrm{~m}_{1}, \mathrm{~g}_{1} \mathrm{~m}_{1}, \mathrm{~g}_{0} \mathrm{~m}_{1}, \mathrm{~g}_{1} \mathrm{~m}_{0}, \mathrm{~g}_{0} \mathrm{~m}_{0}$ dan $\mathrm{g}_{2} \mathrm{~m}_{0}$ Perlakuan $\mathrm{g}_{1} \mathrm{~m}_{2}$ tidak berbeda nyata dengan perlakuan $\mathrm{g}_{0} \mathrm{~m}_{2}, \quad \mathrm{~g}_{2} \mathrm{~m}_{1}, \quad \mathrm{~g}_{1} \mathrm{~m}_{1}$, tetapi berbeda nyata dengan perlakuan $\mathrm{g}_{0} \mathrm{~m}_{1}, \mathrm{~g}_{1} \mathrm{~m}_{0}, \mathrm{~g}_{0} \mathrm{~m}_{0}$ dan $\mathrm{g}_{2} \mathrm{~m}_{0}$. Perlakuan $\mathrm{g}_{0} \mathrm{~m}_{2}$ tidak berbeda nyata dengan perlakuan $\mathrm{g}_{2} \mathrm{~m}_{1}, \mathrm{~g}_{1} \mathrm{~m}_{1}$ dan $\mathrm{g}_{0} \mathrm{~m}_{1}$, tetapi berbeda nyata dengan perlakuan $\mathrm{g}_{1} \mathrm{~m}_{0}$, $\mathrm{g}_{0} \mathrm{~m}_{0}$ dan $\mathrm{g}_{2} \mathrm{~m}_{0}$. Perlakuan $\mathrm{g}_{2} \mathrm{~m}_{1}$ tidak berbeda nyata dengan perlakuan $\mathrm{g}_{1} \mathrm{~m}_{1}$, $\mathrm{g}_{0} \mathrm{~m}_{1}, \mathrm{~g}_{1} \mathrm{~m}_{0}, \mathrm{~g}_{0} \mathrm{~m}_{0}$, tetapi berbeda nyata dengan perlakuan $\mathrm{g}_{2} \mathrm{~m}_{0}$. Perlakuan $\mathrm{g}_{0} \mathrm{~m}_{1}$, $\mathrm{g}_{1} \mathrm{~m}_{0}, \mathrm{~g}_{0} \mathrm{~m}_{0}$ dan $\mathrm{g}_{2} \mathrm{~m}_{0}$, satu sama lainnya saling berbeda tidak nyata.

\subsection{Tinggi Tanaman Umur 6 Minggu} Setelah Tanam $(\mathrm{cm})$

Hasil sidik ragam menunjukkan bahwa perlakuan pupuk Green Tonik $(G)$ dan pupuk NPK Mutiara (M) berpengaruh sangat nyata, sedangkan 
interaksinya (GxM) tidak berpengaruh nyata terhadap tinggi tanaman umur 6 minggu setelah tanam (Tabel 1).

Hasil uji BNT taraf 5\% terhadap tinggi tanaman umur 6 minggu setelah tanam pada perlakuan pupuk Green Tonik (G) menunjukkan bahwa perlakuan $\mathrm{g}_{2}$, $\mathrm{g}_{1}$ dan $\mathrm{g}_{0}$ satu sama lainnya saling berbeda nyata.

Hasil uji BNT taraf 5\% terhadap tinggi tanaman umur 6 minggu setelah tanam pada perlakuan pupuk NPK Mutiara (M) menunjukkan bahwa perlakuan $m_{3}, m_{2}, m_{1}$ dan $m_{0}$ satu sama lainnya saling berbeda nyata.

\subsection{Umur Keluar Bunga Jantan (hari)}

Hasil sidik ragam menunjukkan bahwa perlakuan pupuk Green Tonik (G) dan interaksinya (GxM) tidak berpengaruh nyata, sedangkan perlakuan pupuk NPK Mutiara (M) berpengaruh sangat nyata terhadap umur keluar bunga jantan (Tabel 1).

Hasil uji BNT taraf 5\% terhadap umur keluar bunga jantan pada perlakuan pupuk NPK Mutiara (M) menunjukkan bahwa perlakuan $m_{3}$ berbeda nyata dengan perlakuan $\mathrm{m}_{2}, \mathrm{~m}_{1}$ dan $\mathrm{m}_{0}$. Perlakuan $\mathrm{m}_{2}$ tidak berbeda nyata dengan perlakuan $\mathrm{m}_{1}$, tetapi berbeda nyata dengan perlakuan $\mathrm{m}_{0}$. Perlakuan $\mathrm{m}_{1}$ tidak berbeda nyata dengan perlakuan $\mathrm{m}_{0}$.

\subsection{Umur Keluar Bunga Betina (hari)}

Hasil sidik ragam menunjukkan bahwa perlakuan pupuk Green Tonik (G) dan interaksinya (GxM) tidak berpengaruh nyata, sedangkan perlakuan pupuk NPK Mutiara (M) berpengaruh sangat nyata terhadap umur keluar bunga betina (Tabel 1).

Hasil uji BNT taraf 5\% terhadap umur keluar bunga betina pada perlakuan pupuk NPK Mutiara (M) menunjukkan bahwa perlakuan $m_{3}$ berbeda nyata dengan perlakuan $\mathrm{m}_{3}$ tidak berbeda nyata dengan perlakuan $m_{2}$, tetapi berbeda nyata dengan perlakuan $\mathrm{m}_{1}$ dan $\mathrm{m}_{0}$. Perlakuan $\mathrm{m}_{2}$ tidak berbeda nyata dengan perlakuan $\mathrm{m}_{1}$, tetapi berbeda nyata dengan perlakuan $\mathrm{m}_{0}$. Perlakuan $\mathrm{m}_{1}$ tidak berbeda nyata dengan perlakuan $\mathrm{m}_{0}$.

\subsection{Umur Panen (hari)}

Hasil sidik ragam menunjukkan bahwa perlakuan pupuk Green Tonik (G) dan interaksinya (GxM) tidak berpengaruh nyata, sedangkan perlakuan pupuk NPK Mutiara (M) berpengaruh sangat nyata terhadap umur panen (Tabel $1)$.

Hasil uji BNT taraf 5\% terhadap umur panen pada perlakuan pupuk NPK Mutiara (M) menunjukkan bahwa perlakuan $m_{3}$ berbeda nyata dengan perlakuan $\mathrm{m}_{2}, \mathrm{~m}_{1}$ dan $\mathrm{m}_{0}$. Perlakuan $\mathrm{m}_{2}$ tidak berbeda nyata dengan perlakuan $\mathrm{m}_{1}$, tetapi berbeda nyata dengan perlakuan $\mathrm{m}_{0}$. Perlakuan $\mathrm{m}_{1}$ tidak berbeda nyata dengan perlakuan $\mathrm{m}_{0}$.

\subsection{Panjang Tongkol $(\mathrm{cm})$}

Hasil sidik ragam menunjukkan bahwa perlakuan pupuk Green Tonik (G) dan interaksinya (GxM) tidak berpengaruh nyata, sedangkan perlakuan pupuk NPK Mutiara (M) berpengaruh sangat nyata terhadap panjang tongkol (Tabel 1).

Hasil uji BNT taraf 5\% terhadap panjang tongkol pada perlakuan pupuk NPK Mutiara (M) menunjukkan bahwa perlakuan $\mathrm{m}_{3}$ tidak berbeda nyata dengan perlakuan $\mathrm{m}_{2}$ dan $\mathrm{m}_{1}$, tetapi berbeda nyata dengan perlakuan $\mathrm{m}_{0}$. Perlakuan $\mathrm{m}_{2}$ tidak berbeda nyata dengan perlakuan $\mathrm{m}_{1}$, tetapi berbeda nyata dengan perlakuan $\mathrm{m}_{0}$. Perlakuan $\mathrm{m}_{1}$ tidak berbeda nyata dengan perlakuan $\mathrm{m}_{0}$.

\subsection{Diameter Tongkol (cm)}

Hasil sidik ragam menunjukkan bahwa perlakuan pupuk Green Tonik (G) dan interaksinya (GxM) tidak berpengaruh nyata, sedangkan perlakuan 
pupuk NPK Mutiara (M) berpengaruh sangat nyata terhadap diameter tongkol (Tabel 1).

Hasil uji BNT taraf 5\% terhadap panjang tongkol pada perlakuan pupuk NPK Mutiara (M) menunjukkan bahwa perlakuan $m_{3}$ tidak berbeda nyata dengan perlakuan $\mathrm{m}_{2}$, tetapi berbeda nyata dengan perlakuan $\mathrm{m}_{1}$ dan $\mathrm{m}_{0}$. Perlakuan $\mathrm{m}_{2}$ berbeda nyata dengan perlakuan $\mathrm{m}_{1}$ dan $\mathrm{m}_{0}$. Perlakuan $\mathrm{m}_{1}$ tidak berbeda nyata dengan perlakuan $\mathrm{m}_{0}$.

\subsection{Produksi Tongkol (ton/ha)}

Hasil sidik ragam menunjukkan bahwa perlakuan pupuk Green Tonik (G), pupuk NPK Mutiara (M) serta interaksinya $(\mathrm{GxM})$ berpengaruh sangat nyata terhadap produksi tongkol (Tabel 1).

Hasil uji BNT taraf 5\% terhadap produksi tongkol pada perlakuan pupuk Green Tonik (G) menunjukkan bahwa perlakuan $\mathrm{g}_{2}$ berbeda nyata dengan perlakuan $g_{1}$ dan $g_{0}$. Perlakuan $g_{1}$ tidak berbeda nyata dengan perlakuan $\mathrm{g}_{0}$.

Hasil uji BNT taraf 5\% terhadap produksi tongkol pada perlakuan pupuk NPK Mutiara (M) menunjukkan bahwa perlakuan $m_{3}$ berbeda nyata dengan perlakuan $\mathrm{m}_{2}, \mathrm{~m}_{1}$ dan $\mathrm{m}_{0}$. Perlakuan $\mathrm{m}_{2}$ berbeda nyata dengan perlakuan $\mathrm{m}_{1}$ dan $\mathrm{m}_{0}$. Perlakuan $\mathrm{m}_{1}$ tidak berbeda nyata dengan perlakuan $\mathrm{m}_{0}$.

Hasil uji BNT taraf 5\% terhadap produksi tongkol pada interaksi perlakuan pupuk Green Tonik dan pupuk NPK Mutiara (GxM) menunjukkan bahwa perlakuan $\mathrm{g}_{2} \mathrm{~m}_{3}$ berbeda nyata dengan perlakuan $\mathrm{g}_{2} \mathrm{~m}_{2}, \mathrm{~g}_{0} \mathrm{~m}_{3}, \mathrm{~g}_{1} \mathrm{~m}_{3}, \mathrm{~g}_{0} \mathrm{~m}_{2}, \mathrm{~g}_{1} \mathrm{~m}_{2}$ $\mathrm{g}_{0} \mathrm{~m}_{1}, \mathrm{~g}_{0} \mathrm{~m}_{0}, \mathrm{~g}_{2} \mathrm{~m}_{1}, \mathrm{~g}_{1} \mathrm{~m}_{1}, \mathrm{~g}_{2} \mathrm{~m}_{0}$ dan $\mathrm{g}_{1} \mathrm{~m}_{0}$. Perlakuan $\mathrm{g}_{2} \mathrm{~m}_{2}$ tidak berbeda nyata dengan perlakuan $\mathrm{g}_{0} \mathrm{~m}_{3}, \mathrm{~g}_{1} \mathrm{~m}_{3}$ dan $\mathrm{g}_{0} \mathrm{~m}_{2}$, tetapi berbeda nyata dengan perlakuan $\mathrm{g}_{1} \mathrm{~m}_{2}{ }^{\prime} \mathrm{g}_{0} \mathrm{~m}_{1}, \mathrm{~g}_{0} \mathrm{~m}_{0}, \mathrm{~g}_{2} \mathrm{~m}_{1}, \mathrm{~g}_{1} \mathrm{~m}_{1}, \mathrm{~g}_{2} \mathrm{~m}_{0}$ dan $\mathrm{g}_{1} \mathrm{~m}_{0}$. Perlakuan $\mathrm{g}_{0} \mathrm{~m}_{3}$ tidak berbeda nyata dengan perlakuan $\mathrm{g}_{1} \mathrm{~m}_{3}, \mathrm{~g}_{0} \mathrm{~m}_{2}$ dan $\mathrm{g}_{1} \mathrm{~m}_{2}$, tetapi berbeda nyata dengan perlakuan $\mathrm{g}_{0} \mathrm{~m}_{1}, \mathrm{~g}_{0} \mathrm{~m}_{0}, \mathrm{~g}_{2} \mathrm{~m}_{1}, \mathrm{~g}_{1} \mathrm{~m}_{1}, \mathrm{~g}_{2} \mathrm{~m}_{0}$ dan $\mathrm{g}_{1} \mathrm{~m}_{0}$. Perlakuan $\mathrm{g}_{1} \mathrm{~m}_{3}$ tidak berbeda nyata dengan perlakuan $\mathrm{g}_{0} \mathrm{~m}_{2}, \mathrm{~g}_{1} \mathrm{~m}_{2} \mathrm{~g}_{0} \mathrm{~m}_{1}$, $\mathrm{g}_{0} \mathrm{~m}_{0}, \mathrm{~g}_{2} \mathrm{~m}_{1}$ dan $\mathrm{g}_{1} \mathrm{~m}_{1}$, tetapi berbeda nyata dengan perlakuan $\mathrm{g}_{2} \mathrm{~m}_{0}$ dan $\mathrm{g}_{1} \mathrm{~m}_{0}$. Perlakuan $\mathrm{g}_{0} \mathrm{~m}_{2}$ tidak berbeda nyata dengan perlakuan $\mathrm{g}_{1} \mathrm{~m}_{2}{ }^{\prime} \mathrm{g}_{0} \mathrm{~m}_{1}, \mathrm{~g}_{0} \mathrm{~m}_{0}$ dan $\mathrm{g}_{2} \mathrm{~m}_{1}$, tetapi berbeda nyata dengan perlakuan. Perlakuan $\mathrm{g}_{1} \mathrm{~m}_{2}{ }^{\prime} \mathrm{g}_{0} \mathrm{~m}_{1}, \mathrm{~g}_{0} \mathrm{~m}_{0}$, $\mathrm{g}_{2} \mathrm{~m}_{1}, \mathrm{~g}_{1} \mathrm{~m}_{1}, \mathrm{~g}_{2} \mathrm{~m}_{0}$ dan $\mathrm{g}_{1} \mathrm{~m}_{0}$ satu sama lainnya saling tidak berbeda nyata.

Tabel 1. Rekapitulasi Data Penelitian Pengaruh Pupuk Green Tonik dan Pupuk NPK Mutiara Terhadap Pertumbuhan dan Hasil Tanaman Jagung Manis (Zea mays var saccharata Sturt.) Varietas Bonanza.

\begin{tabular}{|c|c|c|c|c|c|c|c|c|}
\hline \multirow{2}{*}{$\begin{array}{l}\text { Faktor } \\
\text { Perlakuan }\end{array}$} & \multicolumn{2}{|c|}{$\begin{array}{l}\text { Tinggi Tanaman } \\
(\mathrm{cm})\end{array}$} & \multirow{2}{*}{$\begin{array}{c}\text { Umur } \\
\text { Keluar } \\
\text { Bunga } \\
\text { Jantan } \\
\text { (hari) }\end{array}$} & \multirow{2}{*}{$\begin{array}{c}\text { Umur } \\
\text { Keluar } \\
\text { Bunga } \\
\text { Betina } \\
\text { (hari) }\end{array}$} & \multirow{2}{*}{$\begin{array}{l}\text { Umur } \\
\text { Panen } \\
\text { (hari) }\end{array}$} & \multirow{2}{*}{$\begin{array}{l}\text { Panjang } \\
\text { Tongkol } \\
(\mathrm{cm})\end{array}$} & \multirow{2}{*}{$\begin{array}{c}\text { Diameter } \\
\text { Tongkol } \\
(\mathrm{cm})\end{array}$} & \multirow{2}{*}{$\begin{array}{c}\text { Produksi } \\
\text { Tongkol } \\
\text { (ton/ha) }\end{array}$} \\
\hline & $4 \mathrm{MST}$ & $\begin{array}{l}6 \mathrm{M} \\
\mathrm{HST}\end{array}$ & & & & & & \\
\hline $\begin{array}{c}\text { Pupuk } \\
\text { Green Tonik } \\
\text { (G) } \\
\text { Sidik Ragam } \\
\end{array}$ & $* *$ & $* *$ & tn & tn & tn & tn & tn & $* *$ \\
\hline $\mathrm{g}_{0}$ (kontrol) & $\begin{array}{c}140,58 \\
\text { b }\end{array}$ & $\begin{array}{l}201,08 \\
\quad c\end{array}$ & 49,08 & 54,33 & 82,33 & 21,42 & 4,81 & $15,83 \mathrm{~b}$ \\
\hline $\mathrm{g}_{1}(2 \mathrm{ml} / \mathrm{l}$.air $)$ & $\begin{array}{c}141,25 \\
b\end{array}$ & $\begin{array}{l}202,58 \\
\text { b }\end{array}$ & 48,83 & 54,33 & 82,33 & 22,33 & 4,88 & $16,14 \mathrm{~b}$ \\
\hline $\mathrm{g}_{2}(4 \mathrm{ml} / \mathrm{l}$.air $)$ & $\begin{array}{c}142,17 \\
a\end{array}$ & $\begin{array}{c}205,08 \\
\mathrm{a}\end{array}$ & 48,08 & 54,17 & 82,17 & 22,42 & 4,90 & $16,60 \mathrm{a}$ \\
\hline
\end{tabular}




\begin{tabular}{|c|c|c|c|c|c|c|c|c|}
\hline $\begin{array}{c}\text { Pupuk } \\
\text { NPK Mutiara } \\
\text { (M) } \\
\text { Sidik Ragam } \\
\end{array}$ & $* *$ & $* *$ & $* *$ & $* *$ & $* *$ & $*$ & $* *$ & $* *$ \\
\hline $\mathrm{m}_{0}$ & $\begin{array}{c}139,22 \\
\mathrm{~d}\end{array}$ & $\begin{array}{c}199,22 \\
\mathrm{~d}\end{array}$ & $50,11 \mathrm{c}$ & $54,78 \mathrm{c}$ & $82,89 \mathrm{c}$ & $21,11 \mathrm{~b}$ & $4,76 \mathrm{~b}$ & $15,47 \mathrm{c}$ \\
\hline $\mathrm{m}_{1}$ & $\begin{array}{c}140,22 \\
\mathrm{c}\end{array}$ & $\begin{array}{c}202,33 \\
c\end{array}$ & $\begin{array}{c}48,89 \\
\text { bc }\end{array}$ & $54,44 \mathrm{bc}$ & $\begin{array}{c}82,33 \\
\text { bc }\end{array}$ & $21,78 \mathrm{ab}$ & $4,81 \mathrm{~b}$ & $15,76 \mathrm{c}$ \\
\hline $\mathrm{m}_{2}$ & $\begin{array}{c}141,78 \\
\text { b }\end{array}$ & $\begin{array}{c}204,00 \\
\text { b }\end{array}$ & $48,11 \mathrm{~b}$ & $54,00 \mathrm{ab}$ & $82,00 \mathrm{~b}$ & $22,56 \mathrm{a}$ & $4,93 \mathrm{a}$ & $16,31 \mathrm{~b}$ \\
\hline $\mathrm{m}_{3}$ & $\begin{array}{c}144,11 \\
\mathrm{a} \\
\end{array}$ & $\begin{array}{c}206,11 \\
\mathrm{a} \\
\end{array}$ & $47,56 \mathrm{a}$ & 53,89 a & 81,89 a & 22,78 a & $4,96 \mathrm{a}$ & $17,23 \mathrm{a}$ \\
\hline $\begin{array}{c}\text { Interaksi } \\
\text { (GxM) } \\
\text { Sidik Ragam }\end{array}$ & $*$ & tn & tn & tn & tn & tn & tn & $* *$ \\
\hline $\mathrm{g}_{0} \mathrm{~m}_{0}$ & $\begin{array}{c}139,33 \\
\text { gh }\end{array}$ & 198,33 & 50,67 & 55,00 & 83,00 & 19,33 & 4,60 & $15,31 \mathrm{f}$ \\
\hline $\mathrm{g}_{0} \mathrm{~m}_{1}$ & $\begin{array}{c}139,67 \\
\text { fgh }\end{array}$ & 200,67 & 49,00 & 54,67 & 82,67 & 21,00 & 4,77 & $\begin{array}{c}15,63 \\
\text { def }\end{array}$ \\
\hline $\mathrm{g}_{0} \mathrm{~m}_{2}$ & $\begin{array}{c}141,00 \\
\text { def }\end{array}$ & 201,33 & 48,33 & 54,00 & 82,00 & 22,00 & 4,87 & $\begin{array}{l}15,95 \\
\text { cdef }\end{array}$ \\
\hline $\mathrm{g}_{0} \mathrm{~m}_{3}$ & $\begin{array}{c}142,33 \\
\text { bcd }\end{array}$ & 204,00 & 48,33 & 53,67 & 81,67 & 23,33 & 5,00 & $\begin{array}{c}16,44 \\
\text { bcd }\end{array}$ \\
\hline $\mathrm{g}_{1} \mathrm{~m}_{0}$ & $\begin{array}{c}139,33 \\
\text { gh }\end{array}$ & 197,33 & 49,67 & 55,00 & 83,00 & 22,00 & 4,83 & $\begin{array}{c}15,73 \\
\text { def }\end{array}$ \\
\hline $\mathrm{g}_{1} \mathrm{~m}_{1}$ & $\begin{array}{c}140,33 \\
\text { efgh }\end{array}$ & 201,67 & 49,00 & 54,00 & 82,33 & 22,33 & 4,83 & $\begin{array}{c}15,91 \\
\text { def }\end{array}$ \\
\hline $\mathrm{g}_{1} \mathrm{~m}_{2}$ & $\begin{array}{c}141,67 \\
\text { cde }\end{array}$ & 204,67 & 48,33 & 54,00 & 82,00 & 23,00 & 4,90 & $\begin{array}{l}16,17 \\
\text { bcde }\end{array}$ \\
\hline $\mathrm{g}_{1} \mathrm{~m}_{3}$ & $\begin{array}{c}143,67 \\
\text { b }\end{array}$ & 206,67 & 48,33 & 54,00 & 82,00 & 22,00 & 4,97 & $16,75 \mathrm{bc}$ \\
\hline $\mathrm{g}_{2} \mathrm{~m}_{0}$ & $\begin{array}{c}139,00 \\
\mathrm{~h}\end{array}$ & 202,00 & 50,00 & 54,33 & 82,67 & 22,00 & 4,83 & 15,37 ef \\
\hline $\mathrm{g}_{2} \mathrm{~m}_{1}$ & $\begin{array}{c}140,67 \\
\text { efg }\end{array}$ & 204,67 & 48,67 & 54,33 & 82,00 & 22,00 & 4,83 & $\begin{array}{c}15,73 \\
\text { def }\end{array}$ \\
\hline $\mathrm{g}_{2} \mathrm{~m}_{2}$ & $\begin{array}{c}142,67 \\
\text { bc }\end{array}$ & 206,00 & 47,67 & 54,00 & 82,00 & 22,67 & 5,03 & $16,82 \mathrm{~b}$ \\
\hline $\mathrm{g}_{2} \mathrm{~m}_{3}$ & $\begin{array}{c}146,33 \\
\mathrm{a} \\
\end{array}$ & 207,67 & 46,00 & 54,00 & 82,00 & 23,00 & 4,90 & $18,50 \mathrm{a}$ \\
\hline
\end{tabular}

$\begin{array}{ll}\mathrm{m}_{0} & =\text { tanpa pupuk NPK Mutiara (kontrol) } \\ \mathrm{m}_{1} & =\text { dosis pupuk NPK Mutiara } 100 \mathrm{~kg} / \mathrm{ha} \\ \mathrm{m}_{2} & =\text { dosis pupuk NPK Mutiara } 200 \mathrm{~kg} / \mathrm{ha} \\ \mathrm{m}_{3} & =\text { dosis pupuk NPK Mutiara } 300 \mathrm{~kg} / \mathrm{ha} \\ \mathrm{g}_{0} & =\text { tanpa pupuk Green Tonik (kontrol) } \\ \mathrm{g}_{1} & =\text { konsentrasi pupuk Green Tonik } 2 \mathrm{ml} / \mathrm{l} \text {.air } \\ \mathrm{d}_{2} & =\text { konsentrasi pupuk Green Tonik } 4 \mathrm{ml} / \mathrm{l} \text {.air } \\ \mathrm{tn} & =\text { tidak berpengaruh nyata } \\ * & =\text { berpengaruh nyata } \\ * * & =\text { berpengaruh sangat nyata } \\ \text { MST } & =\text { Minggu Setelah Tanam }\end{array}$


Pengaruh Pupuk Green Tonik Terhadap Tanaman Jagung Manis (Zea mays saccharata Sturt). Hasil sidik ragam menunjukkan bahwa perlakuan pupuk Green Tonik berpengaruh sangat nyata terhadap tinggi tanaman umur 4 minggu dan umur 6 minggu setelah tanam. Tanaman tertinggi terdapat pada perlakuan $\mathrm{g}_{2}$ (konsentrasi pupuk Green Tonik $4 \mathrm{ml} / \mathrm{l}$.air), yaitu $142,17 \mathrm{~cm}$ pada umur 4 minggu, dan 205,08 $\mathrm{cm}$ pada umur 6 minggu setelah tanam, sedangkan tanaman terendah terdapat pada perlakuan $\mathrm{g}_{0}$ (perlakuan tanpa pupuk Green Tonik atau kontrol), yaitu 140,58 $\mathrm{cm}$ pada umur 4 minggu dan 201,08 $\mathrm{cm}$ pada umur 6 mingu setelah tanam. Semakin meningkat pupuk Green Tonik yang diberikan, maka semakin meningkat pula tinggi tanaman. Keadaan ini disebabkan adanya peranan unsur nitrogen $(\mathrm{N})$ yang terdapat dalam pupuk Green Tonik (kadarnya 14,73 $\% \mathrm{~N}_{2}$ ). Dengan bertambahnya umur tanaman jagung manis, maka kebutuhan terhadap unsur hara bertambah banyak. Perlakuan pemberian pupuk Greeen Tonik menghasilkan tanaman yang lebih tinggi dibandingkan dengan perlakuan tanpa pupuk Green Tonik. Hal ini disebabkan dengan pemberian pupuk Green Tonik melalui daun, maka akan meningkatkan ketersedian unsur hara dalam tubuh tanaman, terutama unsur hara nitrogen (N) yang sangat dibutuhkan untuk pertumbuhan vegetatif tanaman. Seperti dikemukakan oleh Mulyani Sutedjo (2002) yang menyatakan bahwa dengan pemberian unsur nitogen, tanaman akan banyak mengandung zat hijau daun yang penting dalam proses fotosintesis dan mempercepat pertumbuhan dan bertambahnya tinggi tanaman. Ditambahkan oleh Sutedjo dan Kartasapoetra (1990) yang menyatakan bahwa ketersediaan unsur $\mathrm{N}$ di dalam tubuh tanaman dapat menghasilkan protein yang lebih banyak, semakin banyak unsur nitrogen yang diberikan, maka semakin cepat pula sintesis karbohidrat yang diubah menjadi protein dan protoplasma. Peningkatan jumlah unsur nitrogen dalam tubuh tanaman akan meningkatkan kadar protein dalam jaringan tanaman yang digunakan dalam pertumbuhan vegetatif tanaman.

Hasil sidik ragam menunjukkan bahwa perlakuan pupuk Green Tonik tidak berpengaruh nyata terhadap umur keluar bunga jantan, umur keluar bunga betina dan umur panen. Keadaan ini disebabkan pada saat terjadi peralihan fase pertumbuhan vegetatif ke fase pertumbuhan generatif yang ditandai dengan keluarnya bunga, selain ditentukan oleh faktor lingkungan (faktor luar) juga ditentukkan oleh faktor dalam tanaman itu sendiri. Pada keadaan ini pupuk Green Tonik sebagai faktor pertumbuhan eksternal (faktor luar), tidak berpengaruh terhadap masa pembungan, Seperti dikemukakan Gardner dkk. (1991) bahwa pertumbuhan dan perkembangan tanaman dipengaruhi sifat genetik tanaman dan faktor lingkungan seperti curah hujan, temperatur dan kondisi tanah.

Hasil sidik ragam menunjukkan bahwa perlakuan pupuk Green Tonik tidak berpengaruh nyata terhadap panjang tongkol dan diameter tongkol. Rata-rata panjang tongkol $21 \mathrm{~cm}$ dan diameter tongkol $4 \mathrm{~cm}$. Keadaan in disebabkan bahwa pemberian pupuk Green Tonik lewat daun kurang efektif pada saat penelitian, karena bertepatan dengan datangnya musim hujan yang terjadi hampir setiap hari, sehingga banyak pupuk yang tercuci oleh air hujan dan belum sempat diserap oleh daun.

Hasil sidik ragam menunjukkan bahwa perlakuan pupuk Green Tonik berpengaruh sangat nyata terhadap produksi tongkol. Keadaan ini diduga bahwa dengan terakumulasinya panjang tongkol dan diameter tongkol, walaupun 
tidak berpengaruh nyata, tetapi panjang tongkol dan diameter tongkol cendrung bertambah, yang merupakan komponen pembentuk produksi tongkol, sehingga menghasilkan produksi tongkol yang berbeda sesuai konsentrasi pupuk Green Tonik yang diberikan.

Pengaruh Pupuk NPK Mutiara Terhadap Tanaman Jagung Manis (Zea mays saccharata Sturt). Hasil sidik ragam menunjukkan bahwa perlakuan pupuk NPK Mutiara berpengaruh sangat nyata terhadap tinggi tanaman umur 4 minggu dan umur 6 minggu setelah tanam. Tanaman tertinggi terdapat pada perlakuan $\mathrm{m}_{3}$ (dosis pupuk $300 \mathrm{~kg} / \mathrm{ha}$ ), yaitu $144,11 \mathrm{~cm}$ pada umur 4 mimggu dan 206,11 cm setelah tanam, sedangkan tanaman terendah terdapat pada perlakuan $\mathrm{m}_{0}$ (tanpa pupuk NPK Mutiara atau kontrol), yaitu 139,22 cm pada umur 4 minggu dan 199,22 $\mathrm{cm}$ pada umur 6 minggu setelah tanam. Terjadinya pertumbuhan tinggi yang signifikan pada perlakuan dengan dosis pupuk NPK Mutiara dibandingkan dengan perlakuan lainnya, keadaan ini diduga disebabkan pengaruh unsur nitrogen $(\mathrm{N})$ dengan kadar $15 \% \mathrm{~N}_{2}$, yang terdapat pada pupuk tersebut, yang mempunyai peran dalam pertumbuhan vegetatif tanaman, terutama dalam pertumbuhan tinggi, jumlah daun dan perkembangan akar. Sebagaimana dikemukakan oleh Novizan (2002) bahwa unsur nitrogen dibutuhkan pada tahap pertumbuhan vegetatif, seperti pembentukan tunas atau perkembangan batang dan daun.

Hasil sidik ragam menunjukkan bahwa perlakuan pupuk NPK Mutiara berpengaruh sangat nyata terhadap umur keluar bunga jantan, umur keluar bunga betina dan umur panen. Berdasarkan data pada Tabel 1 (Tabel Rekapitulasi) perlakuan pupuk NPK Mutiara dengan dosis $300 \mathrm{~kg} / \mathrm{ha} \quad\left(\mathrm{m}_{3}\right)$ mempercepat keluarnya bunga jantan, bunga betina dan umur panen, yaitu umur keluar bunga jantan 47,56 hari, umur keluar bunga betina 53,89 hari dan umur panen 82,17 hari, dibandingkan dengan perlakuan tanpa pupuk NPK Mutiara $\left(\mathrm{m}_{0}\right)$, yaitu umur keluar bunga jantan 50,11 hari, umur keluar bunga betina 54,78 hari dan umur panen 82,17 hari. Keadaan ini diduga bahwa unsur hara yang terkandung dalam pupuk NPK Mutiara, yaitu unsur $\mathrm{P}$ dan unsur $\mathrm{K}$ mempengaruhi masa pembungaan dan umur panen. Seperti dikemukakan oleh Novizan (2002), bahwa unsur fosfor (P) dapat merangsang pertumbuhan bunga, buah dan biji, sedangkan unsur kalium peranannya berhubungan dengan proses metabolisme, seperti fotosintesis dan respirasi.

Hasil sidik ragam menunjukkan bahwa perlakuan pupuk NPK Mutiara berpengaruh snyata terhadap panjang tongkol dan berpengaruh sangat nayata terhadap diameter tongkol dan produksi tongkol. Secara umum tongkol terpanjang, diameter terbesar dan produksi tongkol tertinggi per hektar terdapat pada perlakuan $\mathrm{m}_{3}$ (dosis pupuk $300 \mathrm{~kg} / \mathrm{ha}$, yaitu $22,78 \mathrm{~cm}, 4,96 \mathrm{~cm}$ dan 17,23 ton/ha. Sedangkan tongkol terpendek $(21,11 \mathrm{~cm})$, dimeter terkecil $(4,76 \mathrm{~cm})$ dan produksi tongkol terendah per hektar $(15,47$ ton/ha) terdapat pada perlakuan $\mathrm{m}_{0}$ (perlakuan tanpa pupuk NPK Mutiara atau kontrol). Hal ini menunjukkan bahwa pemberian pupuk NPK Mutiara mampu meningkatkan ketersediaan unsur hara di dalam tanah, terutama unsur nitrogen fosfor dan kalium, sehingga memungkinkan akar tanaman untuk menyerap unsur-unsur tersebut, yang diperlukan bagi pertumbuhan generatif tanaman jagung, terutama panjang tongkol, diameter tongkol dan produksi tongkol. Sebagaimana diketahui bahwa unsur nitrogen berperan dalam pembentukan protein, unsur fosfor untuk pembentukan buah atau biji, serta unsur kalium untuk 
pembentukan karbohidrat, yang selanjutkan akan menghasilkan buah jagung (tongkol jagung). Hal ini sesuai dengan pendapat Mulyani Sutedjo (2008), bahwa unsur nitrogen berperan dalam pembentukan protein, unsur fosfor sangat diperlukan dalam pemasakan buah dan biji, serta unsur kalium berfungsi untuk membentuk protein dan karbohidrat yang merupakan persenyawaan organik dalam organ tanaman.

Pengaruh Interaksi Perlakuan Pupuk Green Tonik dan Pupuk NPK Mutiara Terhadap Tanaman Jagung Manis (Zea mays saccharata Sturt). Hasil sidik ragam menunjukkan bahwa interaksi perlakuan antara pupuk Green Tonik dan pupuk NPK Mutiara tidak berpengaruh nyata terhadap parameter tinggi tanaman umur 6 minggu setelah tanam, umur keluar bunga jantan, umur keluar bunga betina, umur panen, panjang tongkol dan diameter tongkol. Berpengaruh nyata terhadap tinggi tanaman umur 4 minggu setelah tanam. Berpengaruh sangat nyata terhadap produksi tongkol.

Secara umum interaksi perlakuan pupuk Green Tonik dan pupuk NPK Mutiara tidak memberikan hasil yang signifikan pada parameter penelitian yang diamati, ada kecendrungan terjadi peningkatan pertumbuhan, baik pada fase pertumbuhan vegetatif, seperti tinggi tanaman, maupun pada pertumtumbuhan generatif, seperti umur berbunga (bunga jantan dan bunga betina), umur panen, panjang tongkol dan diameter tongkol. Khusus komponen produksi seperti panjang tongkol dan diameter tongkol yang cendrung meningkat sesuai perbedaan dosis pupuk yang diberikan, yang pada akhirnya akan terakumulasi pada parameter produksi tongkol per hektar. Produksi tongkol tertinggi terdapat pada interaksi perlakuan $\mathrm{g}_{2} \mathrm{~m}_{3}$ (dosis pupuk Greeen Tonik 4 ml/l.air dan dosis pupuk NPK Mutiara $300 \mathrm{~kg} / \mathrm{ha}$ setara $144 \mathrm{~g} /$ petak), yaitu 18,50 ton/ha, sedangkan produksi tongkol terendah terdapat pada perlakuan $\mathrm{g}_{0} \mathrm{~m}_{0}$ (tanpa pupuk Green Tonik dan pupuk NPK Mutiara), yaitu 15,31 ton/ha. Produksi tongkol yang dihasilkan dari penelitian ini masih sangat rendah bila dibandingkan dengan produksi tongkol yang tertera pada deskripsi jagung manis varietas Bonanza, yaitu 33,00 - 34,50 ton/ha (produksi tongkol dengan kelobot). Rendahnya produksi tongkol jagung manis varietas Bonanza yang telah diteliti, diduga disebabkan kondisi tanah yang kurang subur, ditambah lagi dengan curah hujan yang tinggi selama penelitian dan juga sebagian tanaman pinggir (border) ada yang terendam air, akibat genangan air hujan.

\section{KESIMPULAN}

Kesimpulan dari hasil penelitian adalah : Perlakuan pupuk Green Tonik tidak berpengaruh nyata terhadap parameter umur keluar bunga jantan, umur keluar bunga betina, umur panen, panjang tongkol dan diameter tongkol. Berpengaruh sangat nyata terhadap tinggi tanaman umur 4 minggu dan umur 6 minggu setelah tanam serta produksi tongkol. Produksi tongkol tertinggi terdapat pada perlakuan $\mathrm{g}_{2}$ (konsentrasi pupuk Green Tonik 4 ml/l.air), yaitu 16,60 ton/ha, sedangkan produksi tongkol terendah terdapat pada perlakuan $\mathrm{g}_{0}$ (tanpa pupuk Green Tonik atau kontrol), yaitu 16,14 ton/ha.

Perlakuan pupuk NPK Mutiara berpengaruh nyata terhadap parameter panjang tongkol. Berpengaruh sangat nyata terhadap tinggi tanaman umur 4 minggu dan umur 6 minggu setelah tanam, umur keluar bunga jantan, umur keluar bunga betina, umur panen, diameter tongkol dan produksi tongkol. Produksi tongkol tertinggi terdapat pada 
perlakuan $\mathrm{m}_{3}$ (dosis pupuk NPK Mutiara $300 \mathrm{~kg} / \mathrm{ha}$ ), yaitu 17,23 ton/ha, sedangkan produksi tongkol terendah terdapat pada perlakuan $m_{0}$ (tanpa pupuk NPK Mutiara atau kontrol), yaitu 15,47 ton/ha.

Interaksi perlakuan antara pupuk Green Tonik dan pupuk NPK Mutiara tidak berpengaruh nyata terhadap parameter tinggi tanaman umur 6 minggu setelah tanam, umur keluar bunga jantan, umur keluar bunga betina, umur panen, panjang tongkol dan diameter tongkol. Berpengaruh nyata terhadap tinggi tanaman umur 4 minggu setelah tanam. Berpengaruh sangat nyata terhadap produksi tongkol. Produksi tongkol tertinggi terdapat pada perlakuan $\mathrm{g}_{2} \mathrm{~m}_{3}$ (konsentrasi pupuk Green Tonik 4 ml/l.air dan dosis pupuk NPK Mutiara $300 \mathrm{~kg} / \mathrm{ha}$ ), yaitu 18,50 ton/ha, sedangkan produksi tongkol terendah terdapat pada perlakuan $\mathrm{g}_{0} \mathrm{~m}_{0}$ (tanpa pupuk Green Tonik dan pupuk NPK Mutiara), yaitu 15,73 ton/ha.

\section{DAFTAR PUSTAKA}

Gardner, F.P., R.B. Pearce dan R.L. Mitchell. (1991). Fisiologi Tanaman Budidaya. Jakarta: Universitas Indonesia.

Novizan. (2002). Petunjuk Pemupukan Yang Efektif. Jakarta: Agro Media Pustaka.

Purwono dan Hartono, R. (2007). Bertanam Jagung Unggul. Jakarta: Penebar Swadaya.

Suprapto, H. S. (2004). Bertanam Jagung, Jakarta: Penebar Swadaya,

Sutedjo, M.M. dan Kartasapoetra, A.G. (1990). Pupuk dan Cara Pemupukan. Jakarta: Rineka Cipta. 
Sutedjo, M. M. (2002). Pengantar Ilmu Tanah. Terbentuknya Tanah dan Tanah Pertanian. Jakarta: Rineka Cipta.

Sutedjo, M.M. (2008). Pupuk dan Cara Pemupukan. Jakarta: Rineka Cipta.
Syukur, M. dan Rifianto, A. (2013). Jagung Manis. Jakarta: Penebar Swadaya.

Yitnosumarto, S. (1993). Percobaan, Perancangan, Analisis dan Interpretasinya. Jakarta: Gramedia. 